\title{
Synthesis, Characterization, and Cytotoxicity Evaluation of Gallic Acid Nanoparticles Towards Breast T47D Cancer Cells
}

\author{
Ade Arsianti ${ }^{1,2, *}$, Anton Bahtiar ${ }^{3}$, Fadilah Fadilah ${ }^{1,2}$, Vincent Kharisma Wangsaputra ${ }^{4}$, Rafika Indah Paramita ${ }^{1}$, \\ Norma Nur Azizah ${ }^{2}$, Lince Dameria Nadapdap², Ajeng Megawati Fajrin' ${ }^{1}$, Hiroki Tanimoto ${ }^{5}$, Kiyomi Kakiuchi ${ }^{5}$
}

\begin{abstract}
Ade Arsianti ${ }^{1,2, *}$, Anton Bahtiar ${ }^{3}$, Fadilah Fadilah ${ }^{1,2}$, Vincent Kharisma Wangsaputra ${ }^{4}$, Rafika Indah Paramita ${ }^{1}$, Norma Nur Azizah², Lince Dameria Nadapdap ${ }^{2}$, Ajeng Megawati Fajrin', Hiroki Tanimoto ${ }^{5}$, Kiyomi Kakiuchi $^{5}$
\end{abstract}

'Department of Medical Chemistry, Faculty of Medicine, University of Indonesia, Jakarta, INDONESIA.

${ }^{2}$ Drug Development Research Cluster, Indonesia Medical Education and Research Institute (IMERI), Faculty of Medicine, University of Indonesia, Jalan Salemba Raya 6 Jakarta 10430, INDONESIA.

${ }^{3}$ Department of Pharmacology, Faculty of Pharmacy, University of Indonesia, Depok, INDONESIA.

${ }^{4}$ Medical Student, Faculty of Medicine University of Indonesia, Jakarta, INDONESIA. ${ }^{5}$ Graduate School of Materials Science, Nara Institute of Science and Technology (NAIST), 8916-5 Takayama-cho, Ikoma, Nara, JAPAN.

\section{Correspondence}

\section{Dr. Ade Arsiant}

Department of Medical Chemistry, Faculty of Medicine University of Indonesia, Depok, INDONESIA.

Phone no: +6281312581253

E-mail: arsi_ade2002@yahoo.com

History

- Submission Date: 08-12-2019;

- Review completed: 26-12-2019;

- Accepted Date: 22-01-2020

DOI : 10.5530/pj.2020.12.51

Article Available online

http://www.phcogj.com/v12/i2

\section{Copyright}

(C) 2020 Phcogi.Com. This is an openaccess article distributed under the term of the Creative Commons Attribution 4.0 International license.

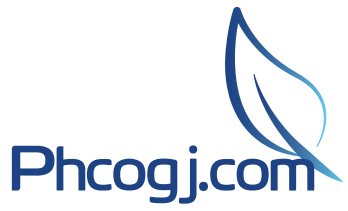

\section{ABSTRACT}

Introduction: Gallic acid is a naturally polyphenolic acid which shows cytotoxicity against several cancer cells, as well as it displays chemo-preventive activity which is attributed to its strong apoptosis- inducing and antioxidant effects. Thus, gallic acid has become an attractive substance to be further developed due to its strong cytotoxic activity. This study aimed to synthesize gallic acid nanoparticle coating with alginate-chitosan, and evaluate its cytotoxicity against breast T47D cancer cells. Methods: Gallic acid nanoparticle was synthesized using ionic gelation method. The yield, size and morphology of the nanoparticles were determined by UV-Vis Spectroscopy, Transmission electron microscopy (TEM) and Fourier Transform Infrared (FTIR) spectroscopy. Cytotoxicity evaluation of gallic acid nanoparticle towards breast T47D cancer cell is carried out by MTT(3-[4,5-dimethylthiazol-2-yl]-2,5-diphenyltetrazoliumbromide) assay. Results: Spherical nanoparticles of gallic acid with the size of $100-200 \mathrm{~nm}$ has been successfully synthesized in $96 \%$ of yield. Compared to gallic acid $\left(\mathrm{IC}_{50}: 20.86 \mu \mathrm{g} / \mathrm{mL}\right.$ ) and alginate-chitosan nanoparticle $\left(\mathrm{IC}_{50}: 38.46 \mu \mathrm{g} / \mathrm{mL}\right)$, gallic acid coating with alginate-chitosan nanoparticles demonstrated higher cytotoxicity towards breast T47D cancer cells with $I_{50}$ value of $9.03 \mu \mathrm{g} / \mathrm{mL}$. Conclusion: Our results clearly confirmed that gallic acid nanoparticles coating with alginate-chitosan showed a strong cytotoxicity towards breast T47D cancer cells, which is potential to be developed as a candidate for new anti-breast cancer agent.

Key words: Synthesis; Gallic acid; Nanoparticle; Cytotoxicity; T47D cells.

\section{INTRODUCTION}

3,4,5-trihydroxybenzoic acid, also known as gallic acid (Figure 1), is a polyphenolic compound found in plants and fruits such as mangoes, grapeseeds, raspberry, etc. Gallic acid is known to have anticancer, antimicrobial, and antiviral properties. ${ }^{1-}$ ${ }^{4} \mathrm{~A}$ research by Wang et al. in 2014 showed that gallic acid has anticancer effects towards MCF7 breast cancer cells by inhibiting the cancer cells proliferation and inducing apoptosis. Gallic acid works by activating the Fas/FasL apoptotic pathway. In addition, gallic acid also induces apoptosis through mitochondrial pathway. Gallic acid is hydrophilic, causing it difficult to penetrate into the wall of cancer cells. ${ }^{5}$ Preparation of gallic acid in form of nanoparticles is believed to increase the hydrophobicity. Therefore, this study aimed to synthesize nanoparticle of gallic acid coating with alginate-chitosan (Figure 1), and evaluate its cytotoxicity toward breast T47D cancer cells. Gallic acid coated alginate-chitosan nanoparticle is expected to be able to diffuse easily through the cancer cell membrane, that may lead to the increasing in its absorption and bioavailability, as well as the improvement of its anticancer activity.

Nanoparticles are particles between 1-1000 nanometre in size. In the field of Pharmacy, nanoparticles have two meanings/interpretations, namely the nanometre-sized drug compounds or nanocrystal, and drug compounds that are encapsulated in nanometre-sized carrier system termed as nanocarriers. ${ }^{6}$ There are several types of nanocarriers, such as nanotubes, liposomes, solid lipid nanoparticles, polymeric nanoparticles, etc.' The carrier polymer can be chitosan, which is a polysaccharide derived from chitin deacetylation process. Chitosan can be utilized in mucoadhesive drug delivery systems because its positively charged polymer chains can interact electrostatically with the negatively charged mucose. ${ }^{8}$ In 2018, Adhikari and Yadav reported that chitosan and its derivatives had anticancer activity through cellular enzymatic, antiangiogenic and apoptotic pathways. ${ }^{9}$ Whereas alginate, is a polysacharride polymer that can be obtained from brown algae with $\alpha$-L-guluronic acid and $\beta$-D-mannuronic acid as the constituent monomers. Alginate is easily dissolved and degraded under normal physiological conditions, making it suitable to be used as systemic drug delivery. ${ }^{10}$ Chitosan-alginate nanoparticles can be prepared, for example, by using the ionic gelation method. This method has some advantages such as simple preparation process with mild conditions without using hazardous or toxic organic solvents and without using high temperature heating process that may cause the decomposition of active compounds, so that this method is suitable to be used for the preparation of nanoparticles that contain thermolabile active compounds. ${ }^{11}$ Nanoparticles have several advantages and disadvantages. The advantages of nanoparticles include: the capability to overcome physiological barrier in the body

Cite this article: Arsianti A, Bahtiar A, Fadilah F, Kharisma Wangsaputra V, Paramita RI, Azizah NN, et al. Synthesis, Characterization, and Cytotoxicity Evaluation of Gallic Acid Nanoparticles Towards Breast T47D Cancer Cells. Pharmacog J. 2020;12(2):321-7. 


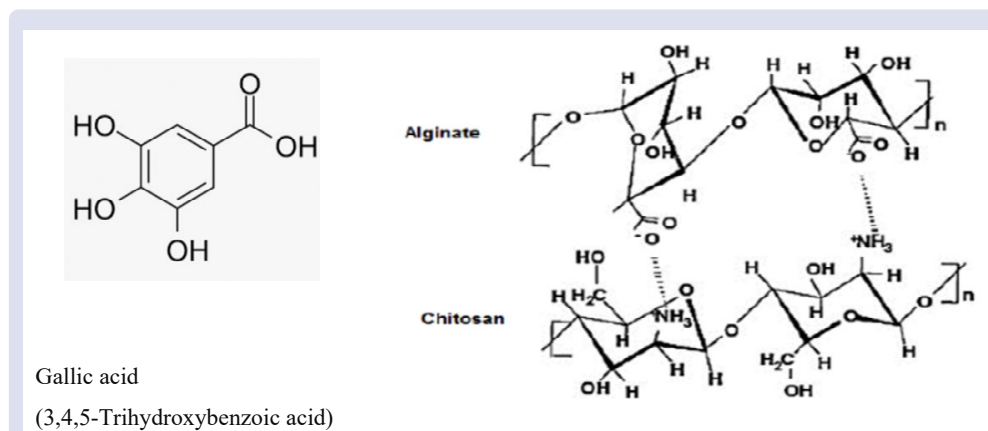

Figure 1: Gallic acid and molecular interaction of alginate-chitosan.

that is caused by the drug delivery system which is influenced by the particle size; increase the solubility of compounds that are poorly water-soluble so that it increases the bioavailability, active compounds stabilility, efficiency of drug distribution and allows better penetration in tumors with pores ranging $100-1000 \mathrm{~nm}$ in diameter. However, the disadvantages of nanoparticles are that they are easily aggregated so that it is difficult in handling and storage; small in size and not suitable for drugs that require large dosage; due to the nanometre size, able to penetrate undesirable parts such as nuclear envelope and cause genetic damage or mutations. ${ }^{8}$ Nanoparticles characterization to determine the physicochemical properties, size, shape, and particles distribution can be done by using some instruments, namely Transmission Electron Microscopy (TEM), Scanning Electron Microscopy (SEM), Nuclear Magnetic Resonance (NMR), Fourier-Transform Infrared Spectroscopy (FTIR), Dynamic Light Scattering (DLS), Static Light Scattering (SLS), etc. ${ }^{12}$

Research about synthesis of gallic acid and its derivatives nanoparticles is still very limited. In 2010, Moreno-Alvarez et al. reported that preparation of gold-gallic acid nanoparticles has antibacterial activity. ${ }^{13} \mathrm{Li}$ and Niu (2015) successfully synthesized silver-gallic acid nanoparticles that have high antimicrobial and low cytotoxicity activities towards normal cells. ${ }^{14}$ Radoman et al. (2015) reported the synthesis and characterization of $\mathrm{TiO}_{2}$ nanoparticles modified with octyl gallate ${ }^{15}$, whilst the latest research by Cordova et al. in 2017 showed that solid lipid-octyl gallate nanoparticles can improve the antimetastatic activity in mice model of lung cancer. ${ }^{16}$ Synthesis and characterization of gallic acid nanoparticles with ionic gelation methods, as well as study to determine the its invitro anticancer activity has never been reported. This serves as the novelty aspect of this research.

\section{MATERIAL}

\section{Chemicals}

Gallic acid, alginate, chitosan, and doxorubicin were purchased from Sigma-Aldrich Chemical Company.

Syntheses of the nanoparticles were conducted in dried glasswares. All chemical solvents in pro analysis grade were purchased from chemical distributor of Brataco Indonesia. Syntheses of the nanoparticles and its cytotoxicity evaluationwere carried out in Departement of Medical Chemistry, Faculty of Medicine, University of Indonesia. UV-Vis and FTIR analysis of the synthesized nanoparticles were conducted in Drug Development Research Cluster, Indonesia Medical Education and Research Institute (IMERI), Faculty of Medicine, University of Indonesia. TEM analysis of the nanoparticles were performed by JEOL TEM 1010, $80 \mathrm{KV}$ (magnification of 40,000x) in Laboratory of TEM and Histology, Ejkman Institute, Jakarta, Indonesia.

\section{Breast T47D cancer cell lines}

Breast T47D cancer cell is the cell culture collection of the Medical Chemistry Department, Faculty of Medicine, University of Indonesia.

\section{METHODS}

Synthesis procedure of gallic acid nanoparticles with ionic gelation method

$100 \mathrm{mg}$ of $\mathrm{CaCl}_{2}$ is dissolved in $50 \mathrm{~mL}$ distilled water, then $50 \mathrm{mg}$ of gallic acid is added, stir it until the solution is homogenized (Solution 1). Amount of $200 \mathrm{mg}$ of Sodium alginate is dissolved in $25 \mathrm{~mL}$ distilled water. The $\mathrm{pH}$ is adjusted until 5.1 with $0.01 \mathrm{M} \mathrm{HCl}$ (Solution 2). Subsequently, the solution 1 is dropped into Solution 2 by using a syringe. Then, stir at the speed of $1400 \mathrm{rpm}$ for 24 hours (Solution A). Amount of $100 \mathrm{mg}$ of chitosan is dissolved in $25 \mathrm{~mL}$ of $1 \%(\mathrm{v} / \mathrm{v})$ of glacial acetic acid. The $\mathrm{pH}$ is adjusted until 5.5 with $1 \mathrm{~N} \mathrm{NaOH}$, then added $0.31 \mathrm{~g}$ of Tween 80 , and stir it for 24 hours at $60^{\circ} \mathrm{C}$ (Solution B). Solution B is then dropped into Solution A by using syringe whilst being stirred at the speed of $1300 \mathrm{rpm}$ for an hour. The mixture is then centrifuged at $3000 \mathrm{rpm}$ for 10 minutes until the nanoparticles are obtained in the form of pellets. The synthesized nanoparticle were freeze dried prior to use for analysis. Alginate-chitosan nanoparticles were prepared by using the same procedure with the synthesis of gallic acid nanoparticles, but without the addition of gallic acid.

\section{Procedure of in vitro cytotoxicity determation of the nanoparticles by MTT assay}

Breast T47D cells are seeded in RPMI 1640 (Gibco, USA) culture medium, which has been supplemented with $10 \%$ fetal bovine serum (Gibco, USA). Then, it is incubated at $37^{\circ} \mathrm{C}$ in a humidified atmosphere of $4 \% \mathrm{CO}_{2}$. The cell viability is determined by $0.1 \%$ trypan blue method. The test sample (nanoparticle) is diluted to reach the final concentration are $51.2 ; 25.6 ; 12.8 ; 6.4 ; 3.2 ; 1.6 ; 0.8 ; 0.4 \mu \mathrm{g} / \mathrm{mL}$. Diluted samples were added to the target cells, and incubated for 48 hours. Amount of $100 \mu \mathrm{l}$ of $5 \mathrm{mg} / \mathrm{mL}$ of MTT phosphate-buffered saline (PBS) was then added into the target cells of breast T47D in well plate, and the mixtures were reincubated for 4 hours. The mixtureswere then centrifuged, the medium is separated. DMSO in amount of $200 \mu \mathrm{l}$ is added to each well to dissolve the blue purple-colored sediments. The absorbance is measured at $590 \mathrm{~nm}$ on a microplate reader model 550 (Bio-Rad, USA). The inhibition (in \%) was calculated by using the formula below:

$$
\left.\% \text { inhibition=1-( } \frac{\text { Absorbance of treatment group }}{\text { Absorbance of control group }}\right) \times 100 \%
$$

Cytotoxicities of the nanoparticles are expressed by median inhibitory concentration $\left(\mathrm{IC}_{50}\right)$ value. The results will be compared with free-gallic acid (gallic acid not in form of nanoparticle) and doxorubicin as a positive control. 


\section{RESULTS AND DISCUSSION}

In this work, chitosan polymer is used as nanocarrier. Chitosan is nontoxic, biocompatible, and biodegradable, but it is very fragile. Therefore, it requires alginate as a cross-linker to make it more stable. It has been reported that biopolymeric alginate-chitosan nanoparticle is effective and stable as an anticancer drug delivery ${ }^{17,18}$, in which, inspired us to perform the synthesis of gallic acid nanoparticles coating with alginatechitosan biopolymer.

Analysis of \% yield of the synthesized gallic acid nanoparticles by UV-vis spectrophotometry

Liquid (filtrate) obtained from centrifugation of the mixture of the synthesized nanoparticles was analyzed by UV-Vis spectroscopy at $690 \mathrm{~nm}$ to determine the concentration of free-gallic acid (gallic acid which did not convert into nanoparticles). Absorbance data of gallic acid standar solution are displayed in Table 1. Calibration curve of linear regression with the equation: $\mathrm{y}=0.005 \mathrm{x}-0.0062$, is obtained by plotting absorbance (mean value from three replication) of gallic acid in $\mathrm{Y}$ axis with the concentration of gallic acid ( $\mathrm{ppm}$ ) in $\mathrm{X}$ axis (Figure 2). The concentration of free-gallic acid $(\mathrm{x}=20.4867 \mathrm{ppm})$ is generated by substituting $\mathrm{Y}$ in linear line equation of $\mathrm{Y}=0,005 \mathrm{x}-0.0062$ with mean absorbance of filtrate (0.0962). The initial concentration of gallic acid is $500 \mathrm{ppm}$, thus concentration of gallic acid converted into nanoparticle is $479.5133 \mathrm{ppm}$ ( $500 \mathrm{ppm}-20.4867 \mathrm{ppm}$ ). So that, \% yield of synthesized gallic acid nanoparticle is $(479.5133 / 500) \times 100 \%=96 \%$.

\section{TEM analysis of gallic acid nanoparticles}

TEM (Transmission electron microscopy) and SEM (Scanning electron microscopy) can help to identify the shape and size of small particles and nanoparticles. Compared to SEM, TEM has higher resolution. TEM could resolve object near the atomic level, as close as $1 \mathrm{~nm}$. Besides that, SEM's magnifying power is up to 50,000 times, whereas TEM's magnifying power is up to 2 million times. ${ }^{19}$ Therefore, in this work, identification of morphology and size of the synthesized nanoparticle using TEM.

TEM analysis of the nanoparticles (Figure 3) were conducted in Laboratory of TEM and Histology, Ejkman Institute, Jakarta, Indonesia, by using JEOL TEM 1010, $80 \mathrm{KV}$, with magnification of 40,000x. As shown, gallic acid nanoparticles (Figure 3a) have a spherical morphology with the size of 100-200 $\mathrm{nm}$. Whereas alginate-chitosan nanoparticles (Figure $3 b$ ) also have a spherical shape with slightly smaller nanosize.

\section{FTIR analysis of gallic acid nanoparticles}

FTIR is used to confirm the molecular interaction between gallic acid and chitosan-alginate nanocarrier. FTIR analysis of the nanoparticles are displayed in Figure 4a-c. FTIR spectrum of gallic acid (4a) showed sharp band of hydroxyl $(-\mathrm{OH})$ stretching aromatic at $3200-3500 \mathrm{~cm}^{-1}$, absorption of carbonyl $(-\mathrm{C}=\mathrm{O})$ group at $1702 \mathrm{~cm}^{-1}$, and absorption of aromatic carbon at around $1500-1600 \mathrm{~cm}^{-1}$. Whereas, FTIR spectrum of alginate-chitosan nanoparticle ( $4 \mathrm{~b}$ ) showed $\mathrm{N}-\mathrm{H}$ stretching vibration of amine group overlapped with carbonyl $(-\mathrm{C}=\mathrm{O})$ group of alginate at around 1500-1600 $\mathrm{cm}^{-1}$, as well as a broad hydroxyl (-OH) stretching and amine group $(-\mathrm{N}-\mathrm{H})$ band at $3200-3600 \mathrm{~cm}^{-1}$, which indicated the electrostatic interaction and hydrogen bonding between alginate and chitosan. Moreover, a very broad absorption band at 3000-3700 $\mathrm{cm}^{-1}$ in FTIR spectrum of gallic acid nanoparticle (4c) has confirmed the presence of hydrogen bonding between gallic acid and chitosanalginate nanocarrier.

\section{Cytotoxicity of the nanoparticles towards breast T47D cancer cells}

Studies on synthesis of gallic acid nanoparticle are limited. Daduang et al. in 2015 reported the synthesis of gold nanoparticles conjugated with gallic acid (GNPs-GA), and found that GNPs-GA inhibited cervical cancer cells less effective than gallic acid, but it was not toxic against normal vero cells, which indicated that GNPs-GA could be an alternative for cervical cancer treatment with less side effects to the normal cell. ${ }^{20}$ Another researcher, Hu et al. (2015) reported that nanoparticles of gallic

Table 1: UV-vis absorbance data of gallic acid.

\begin{tabular}{cccccc}
\hline $\begin{array}{c}\text { Conc. standard } \\
\text { solution of } \\
\text { Gallic acid (ppm) }\end{array}$ & \multicolumn{4}{c}{ Absorbance } & \multicolumn{2}{c}{$\begin{array}{c}\text { Free-Gallic } \\
\text { acid in filtrate } \\
\text { (ppm) }\end{array}$} \\
\hline 0 & 0.0001 & 0.0001 & 0.0001 & 0.0001 & \\
2 & 0.0090 & 0.0090 & 0.0089 & 0.0090 & 20.4867 \\
4 & 0.0142 & 0.0143 & 0.0141 & 0.0142 & \\
8 & 0.0302 & 0.0301 & 0.0300 & 0.0301 & \\
16 & 0.0556 & 0.0556 & 0.0557 & 0.0556 & \\
32 & 0.1626 & 0.1626 & 0.1626 & 0.1626 & \\
Liquid (Filtrate) & 0.0963 & 0.0962 & 0.0962 & 0.0962 & \\
\hline
\end{tabular}

\section{Calibration curve of gallic acid}

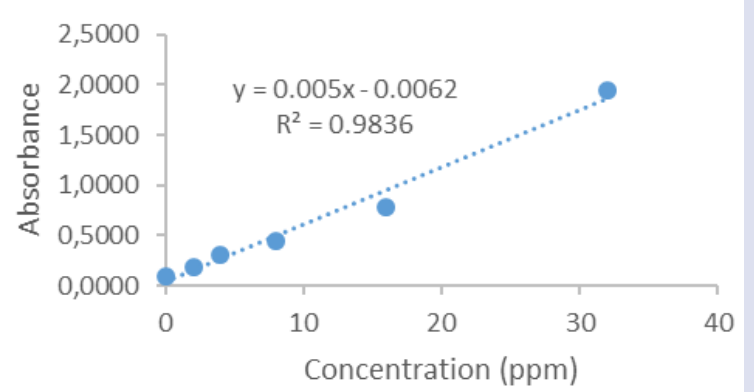

Figure 2: Calibration curve of gallic acid. 


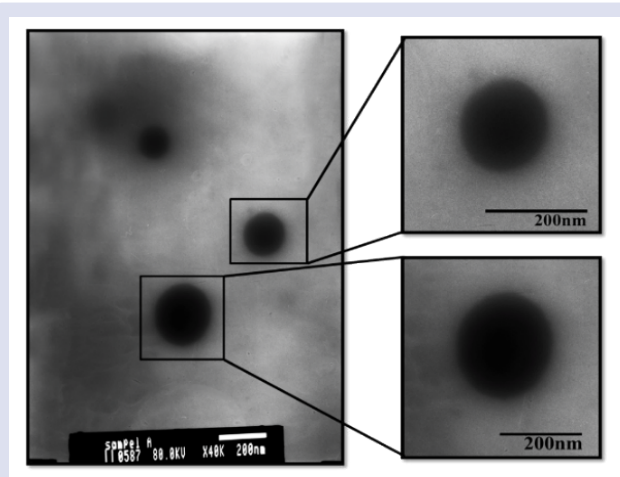

(3a)

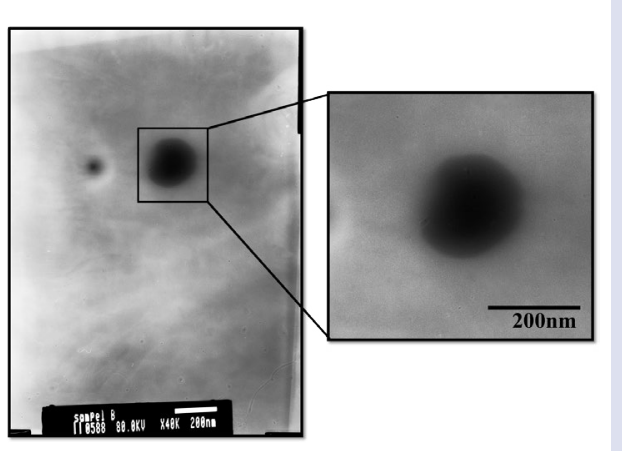

(3b)

Figure 3: TEM images for gallic acid nanoparticle (3a), and alginate-chitosan nanoparticle (3b).

(4a)

$(4 \mathrm{~b})$
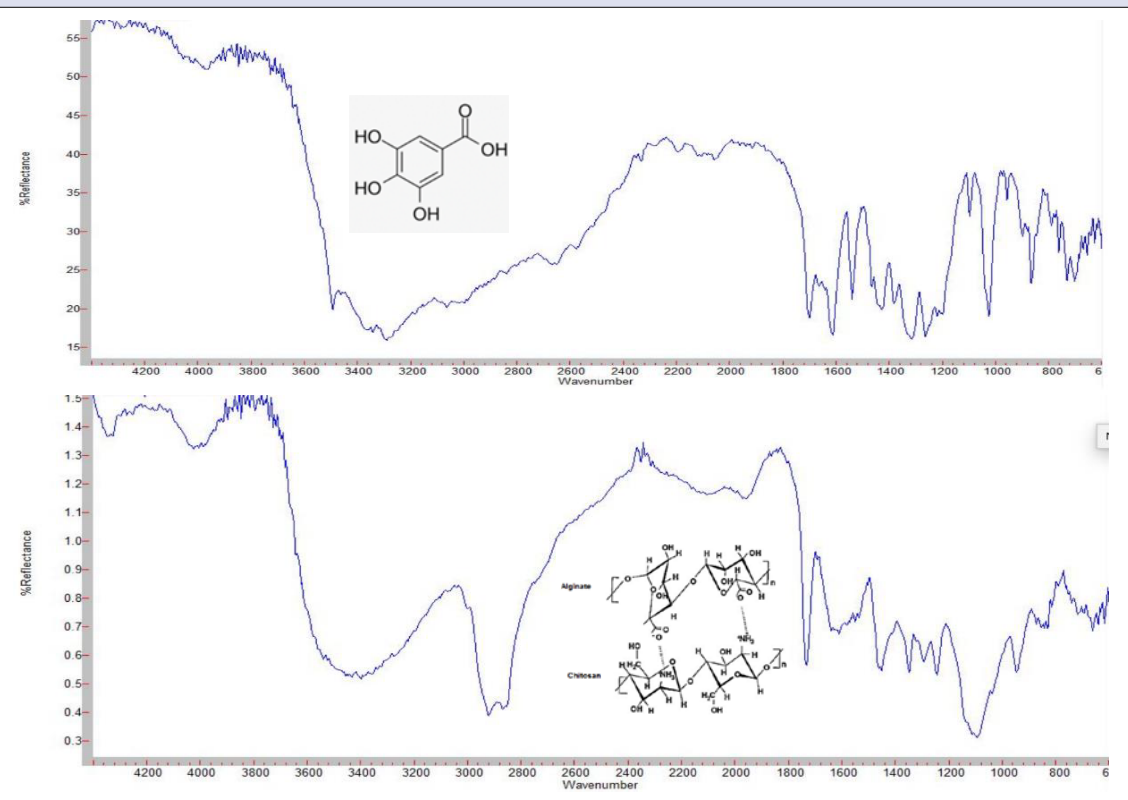

$(4 \mathrm{c})$

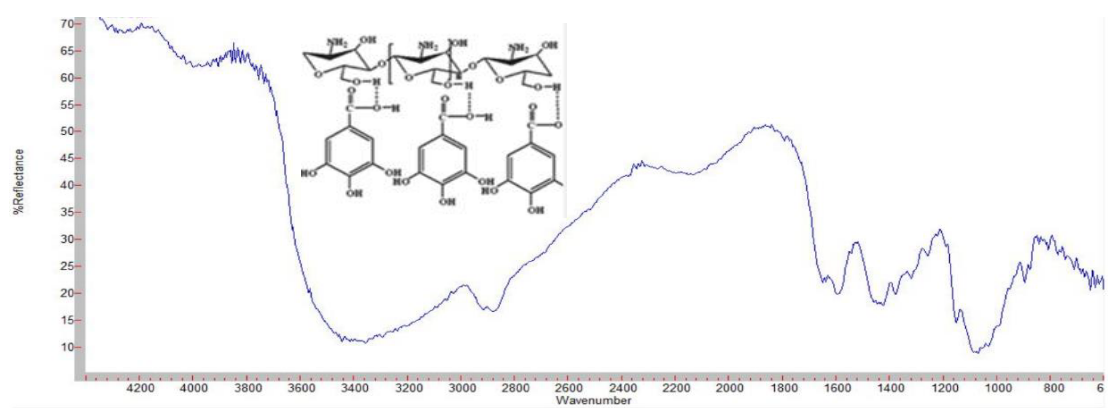

Figure 4: FTIR Spectrum for gallic acid (4a), alginate-chitosan nanoparticle (4b), and gallic acid nanoparticle (4c). 
Table 2: Cytotoxicity of the nanoparticles, free-gallic acid and doxorubicin towards breast T47D cancer cells.

\begin{tabular}{cc}
\hline Tested sample & $\mathrm{IC}_{50}(\mu \mathrm{g} / \mathrm{mL})^{*}$ \\
\hline Doxorubicin (positive control) & $0.10 \pm 0.06$ \\
Gallic acid & $20.86 \pm 3.5$ \\
Alginate-chitosan nanoparticle & $38.46 \pm 4.2$ \\
Gallic acid nanoparticle & $9.03 \pm 2.1$ \\
\hline
\end{tabular}

${ }^{*} \mathrm{IC}_{50}$ is the $50 \%$ half maximal inhibitory activity in $\mu \mathrm{g} / \mathrm{mL}$,expressed in mean value $(\mathrm{n}=3) \pm \mathrm{SD}$ (standard deviation)

acid (GA) grafted chitosan(CS) and caseinophosphopeptides (GA-gCS-CPP). This GA-g-CS-CPP nanoparticles exhibited high antioxidant effect and cytotoxicity against Caco- 2 colon cancer cells. ${ }^{21}$ More recent, Saleh et al. (2019) evaluated anticancer activity of iron oxide-carboxy methyl chitosan (CMC) nanoparticle conjugating with gallic acid (Iron oxide-CMC-GA), and the result showed that the nanoparticles could higher induce the apoptosis in A549 cancer cells compared with WI-38 normal cells. ${ }^{22}$ Furthermore, Wang et al. (2016) investigated anticancer effect of chitosan-coated alginate nanoparticles, and found that chitosan-alginate nanoparticles had cytotoxic effect on Hep2 cells, and could be a promising vehicle for anticancer drug delivery system. ${ }^{18}$

Related to previous works, in this current research we examined in vitro anticancer activity of gallic acid coating with alginatechitosan nanoparticles against breast T47D cells. Table 2 summarizes cytotoxicities of gallic acid coating with alginate-chitosan nanoparticle, alginate-chitosan nanoparticle, gallic acid compound (not in form of nanoparticle), and doxorubicin. As displayed in Table 2, doxorubicin as a positive control has the lowest IC $_{50}$ value, exhibited the strongest cytotoxicity on T47D cells. Compared to gallic acid ( $\mathrm{IC}_{50}: 20.86$ $\mu \mathrm{g} / \mathrm{mL})$ and alginate-chitosan nanoparticle $\left(\mathrm{IC}_{50}: 38.46 \mu \mathrm{g} / \mathrm{mL}\right.$ ), gallic acid coating with alginate-chitosan nanoparticles exhibited greater cytotoxicity on breast T47D cells $\left(\mathrm{IC}_{50}: 9.03 \mu \mathrm{g} / \mathrm{mL}\right)$. This result suggesting that compared to gallic acid compound, gallic acid nanoparticles coating with alginate-chitosan was successfully improved its cytotoxicity against breast T47D cells, due to the increasing in its hydrophobicity. Thus, it should be further developed as a promising candidate for treatment of breast cancer.

\section{CONCLUSION}

Gallic acid nanoparticle coating with alginate-chitosan has been successfully synthesized with ionic gelation method in $96 \%$ of yield. Gallic acid nanoparticle exhibited a strong cytotoxicity towards breast T47D cancer cells with $\mathrm{IC}_{50}$ value of $9.03 \mu \mathrm{g} / \mathrm{mL}$, which is potential to be developed as a candidate for new anti-breast cancer agent.

\section{ACKNOWLEDGEMENT}

Authors especially want to thank Ministry of Research and Technology and Higher Education (Kemenristek-DIKTI), Republic of Indonesia, and Directorate of Research and Public Service (DRPM), University of Indonesia, for the PDUPT (Penelitian Dasar Unggulan Perguruan Tinggi) research grant for fiscal year 2019 (contract number: 1525/ UN2.R3.1/HKP05.00/2019).

\section{CONFLICT OF INTEREST}

The authors declare no conflict of interest.

\section{ABBREVIATIONS}

MTT: 3-(4,5-Dimethylthiazol-2-yl)-2,5-Diphenyltetrazolium Bromide); $\mathbf{I C}_{50}$ : median Inhibitory Concentration; $\boldsymbol{\mu g} / \mathbf{m L}:$ microgram/ milliliter;g: gram; mL: millimeter; N: Normality; DMSO: Dimethyl sulfoxide; UV-Vis: Ultra violet-Visible, FTIR: Fourier Transform Infrared; TEM: Transmission Electron Microscopy; RPMI: Rosewell Park Memorial Institute; h: hour; PBS: Phosphate-Buffered Saline; ${ }^{\circ} \mathbf{C}$ : degree Celsius; $\boldsymbol{\mu L}$ : microliter; $\mathbf{C O}_{2}$ : Carbon dioxide; USA: United States of America.

\section{REFERENCES}

1. Verma S, Singh A, Mishra A. Gallic acid: molecular rival of cancer. Environ Toxicol Phar. 2013;35:473-85.

2. Nabavi SF, Habtemariam S, Jafari M, Sureda A, Nabavi SM. Protective role of gallic acid on sodium fluoride induced oxidative stress in rat brain. Bull Environ Contam Toxicol. 2012;89:73-7.

3. Madlener S, Illmer C, Horvath Z, Saiko P, Losert A, Herbacek I, et al. Gallic acid inhibits ribonucleotide reductase and cyclooxygenases in human $\mathrm{HL}-60$ promyelocytic leukemia cells. Cancer Letters. 2007;245:156-62.

4. Yoon C, Chung S, Lee S, ParkY, Lee S, Park M. Gallic acid, a natural polyphenolic acid, induces apoptosis and inhibits proinflammatory gene expressions in rheumatoid arthritis fibroblast-like synoviocytes. Joint Bone Spine 2013;80(3):274-9.

5. Peng CC, Hsieh CL, Wang HE, Chng JY, Chen KC, Peng RY. Ferulic acid is nephrodamaging while gallic acid is renal protective in long term treatment of chronic kidney disease. ClinNutr. 2012;31:405-14

6. Mohanraj YJ, Chen Y. Nanoparticles- A review. Nigeria: Tropical J Pharm Res 2006:561-73.

7. Rawat $M$, Singh D, Saraf S. Nanocarriers: Promising vehicle for bioactive drugs Biol Pharm Bull. 2006;29(9):1790-8.

8. Ludwig A. The use of mucoadhesive polymers in ocular drug delivery. Adv Drug Deliv Rev. 2005:57(11):1595-639.

9. Adhikari HS, Yadav PN. Anticancer activity of chitosan, chitosan derivatives, and their mechanism of action. International Journal of Biomaterials. 2018;2952085.

10. Sugita P, Kurniati M, Wukirsari T. Enkapsulasi ketoprofen dengankhitosanalginatberdasarkanjenis dan ragamkonsentrasi tween 80 dan span 80. Makara Sains. 2010;14(2):107-12

11. Md N, Eskandari R, Zolfagharian H, Mohammad M. Preparation and in vitro characterization of chitosan nanoparticles containing mesobuthuseupeus scorpion venom as an antigen delivery system. J Venom Anim Toxins Incl Trop Dis. 2012;18(1):44-52

12. Haskell RJ. Physical characterization of nanoparticles, in: Nanoparticles technology for drug delivery. 2006. New York: Taylor \& Francis Group.

13. Moreno-Alvarez SA, Martinez-Castanon GA, Nino-Martinez N, Reyes-Macias JF, Patino-Marin N, Loyolo-Rodriquez JP, et al. Preparation and bactericide activity of gallic acid stabilized gold nanoparticles. J Nanoparticle Res. 2010;12(8):2741-

14. Li D, Niu F. Green synthesis of gallic acid-coated silver nanoparticle with high antimicrobial activity and low cytotoxicity to normal cells. Process Biochem. 2015;50(2):357-66.

15. Radoman TS, Terzic N, Spasojevic PM, Dzunuzovic JV, Marinkovic AD, Jeremic $K B$, et al. Synthesis and characterization of the surface modified titanium dioxide/epoxy nanocomposites. Adv technol. 2015;4(1):7-15.

16. Cordova CAS, Locatelli C, Winter E, Silva AH, Zanetti-Ramos BG, Jasper R, et al. Solid lipid nanoparticles improve octyl gallate antimetastatic activity and ameliorate its renal and hepatic toxic effects. Anti-cancer Drugs. 2017;28(9):97788.

17. Bhunchu S, Roisitthisak P. Biopolymer alginate-chitosan nanoparticles as drug delivery carriers for cancer therapy. Pharmazie. 2014;69(8):563-70.

18. Wang F, Yang S, Yuam J, Gao Q, Huang C. Effective method of chitosancoated alginate nanoparticles for target drug delivery applications. Journal of Biomaterials Applications. 2016;31(1):3-12.

19. Tankeshwar A. Difference between Scanning Electron Microscopy (SEM) and Transmission Electron Microscopy (TEM). 2018

20. Daduang J, Palasap A, Daduang S, Boonsiri P, Suwannalert P, Limpaiboon T Gallic acid enhancement of gold nanoparticle anticancer activity in cervical cancer cells. Asian Pac J Cancer Prev. 2015;16(1):169-74.

21. Hu B, Wang Y, Xie M, Hu G, Ma F, Zeng X. Polymer nanoparticles composed with gallic acid grafted chitosan and bioactive peptides combined antioxidant, anticancer activities and improved delivery property for labile polyphenols. Journal of Functional Foods. 2013;15:593-603.

22. Saleh L, Ragab EA, Abdelhakim HK, Mohamed SH, Zakaria Z. Evaluation of anticancer activities of gallic acid and tartaric acid vectorized on iron oxide nanoparticles. Drug Delivery Lett. 2020 (article in press). 


\section{GRAPHICAL ABSTRACT}

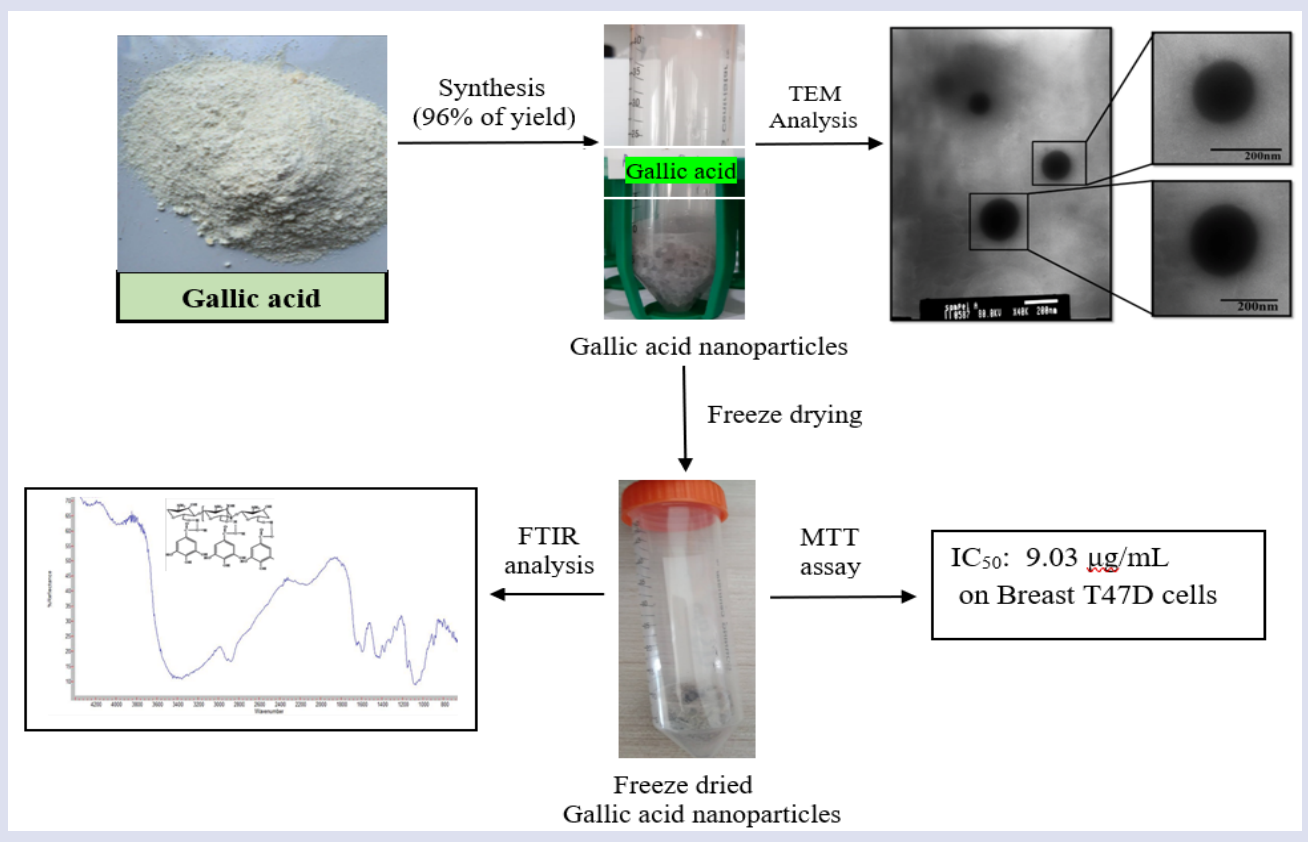

\section{SUMMARY}

Gallic acid has become an attractive substance to be further developed due to its strong anticancer activity. In this work, we succeeded in synthesizing spherical gallic acid nanoparticles coating with alginate-chitosan at the size of $100-200 \mathrm{~nm}$ in $96 \%$ of yield by ionic gelation method. FTIR analysis has confirmed hydrogen bonding between gallic acid and chitosan-alginate nanocarrier. Compared to gallic acid and alginate-chitosan nanoparticle, gallic acid nanoparticle demonstrated higher cytotoxicity towards breast T47D cancer cells with $\mathrm{IC}_{50}$ value of $9.03 \mu \mathrm{g} / \mathrm{mL}$.

\section{ABOUT AUTHORS}

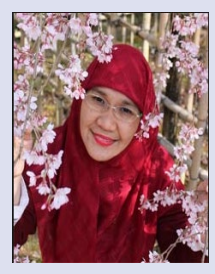

Dr. Ade Arsianti: Lecturer and Researcher at Medical Chemistry Department and Drug Development Research Center (DDRC), Indonesian Medical Education and Research Institute (IMERI), Faculty of Medicine, Universitas Indonesia. Research interest in medicinal chemistry, synthetic organic chemistry, natural product chemistry, and marine natural product.

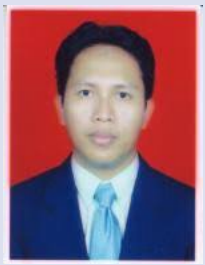

Dr. Anton Bahtiar: Lecturer and Researcher at Department of Pharmacology, Faculty of Pharmacy, Universitas Indonesia. Research interest in molecular pharmacology and herbal medicine.

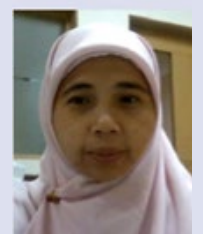

Dr. Fadilah Fadilah: obtained her doctor's degree from the pharmaceutical chemistry, Faculty of pharmacy Universitas Indonesia. She has lecturer and researcher in Drug Development Research Center - IMERI, Bioinformatics Core Facilities - IMERI, Medical Chemistry Departement, Faculty of Medicine Universitas Indonesia, She is an author of 22 research publications including drug discovery from herbal medicine, structure activity relationship analysis, molecular modelling, design and screening of active compounds derivatives. Her current research focuses an using computational simulation of drug development based on gene mutation, analysis of next generation sequencing based on database.

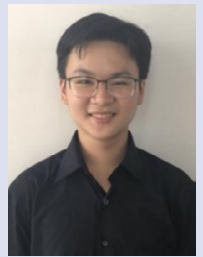

Vincent Kharisma Wangsaputra: Third-year medical student in Faculty of Medicine, Universitas Indonesia. Despite technological advancement in treatment and sophisticated therapeutic strategies, neoplasm still remains as the focus of medical problem causing mortality and morbidity. Many researches have been conducted in order to figure out substances that have high potential of anticancer or cytotoxic activity, especially in combating cell resistance. My personal interest of research includes the utilization and incorporation of Indonesian natural compound to be scientifically applied in a way that it can yield eficient antitumorigenic properties towards the cancer cells. 


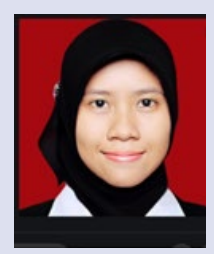

Rafika Indah Paramita: Lecturer and researcher in Drug Development Research Center - IMERI, Bioinformatics Core Facilities - IMERI, Medical Chemistry Departement, Faculty of Medicine Universitas Indonesia. Salemba Raya street number 6, Jakarta, Indonesia - 10430.

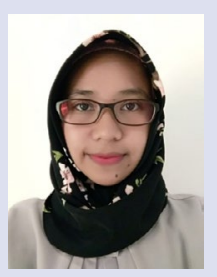

Norma Nur Azizah: Researcher at Drug Development Research Center (DDRC), Indonesian Medical Education and Research Institute (IMERI), Faculty of Medicine, Universitas Indonesia. Research interest in tissue culture, analytical chemistry, and natural product chemistry.

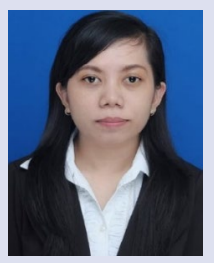

Lince Dameria Nadapdap: Researcher at Drug Development Research Center (DDRC), Indonesian Medical Education and Research Institute (IMERI), Faculty of Medicine, Universitas Indonesia. Research interest in synthetic organic chemistry, analytical chemistry, and natural product chemistry.

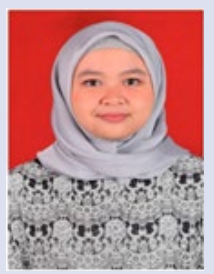

Ajeng Megawati Fajrin: Researcher at Department of Medical Chemistry, Faculty of Medicine, Universitas Indonesia. Research interest in tissue culture, analytical chemistry, and natural product chemistry.

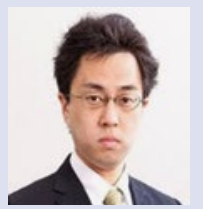

Dr. Hiroki Tanimoto: Assistant Professor and researcher in Synthetic Organic Chemistry Laboratory, Graduate School of Materials Science, Nara Institute of Science and Technology (NAIST), Japan. Research interest in organic synthesis.

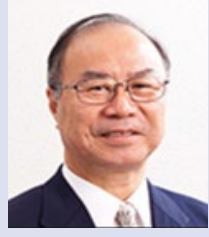

Professor Kiyomi Kakiuchi: Researcher in Synthetic Organic Chemistry Laboratory, Graduate School of Materials Science, Nara Institute of Science and Technology (NAIST), Japan. Research interest in organic synthesis.

Cite this article: Arsianti A, Bahtiar A, Fadilah F, Kharisma Wangsaputra V, Paramita RI, Azizah NN, et al. Synthesis, Characterization, and Cytotoxicity Evaluation of Gallic Acid Nanoparticles Towards Breast T47D Cancer Cells. Pharmacog J. 2020;12(2):321-7. 